\title{
LA ACTIVIDAD PUBLICITARIA CON FINES PROPAGANDÍSTICOS: EL CASO DE LAS RENOVATIONES EPIGRÁFICAS. EL IMPULSO RENOVADOR DEL ABAD JUAN MANSO*
}

Alejandro García Morilla Universidad Isabel I de Castilla / Instituto de Estudios Medievales (ULE)

Recibido: 11 de diciembre de 2017

Aceptado: 3 de julio de 2018

\section{Resumen}

El periodo bajomedieval supone, para algunos grandes monasterios castellanos, un importante proceso de recesión económica y social que contrasta con el periodo de expansión vivido durante los siglos altomedievales. En el siglo XV, la situación se recrudece aún más para los cenobios de ámbito rural debido a la consolidación y auge de los centros urbanos. Ante esta situación, algunos abades tratan de revitalizar sus comunidades mejorando sus infraestructuras y tratando de despertar el interés de peregrinos y visitantes. En estas líneas veremos cómo en esta labor propagandística juega un papel fundamental la escritura publicitaria y más concretamente las Renovationes epigráficas.

\section{Palabras clave}

Epigrafía; inscripción; epitafio; abad; monasterio; propaganda; panteón; renovatio.

\begin{abstract}
For some large Castilian monasteries, the late medieval period entailed an important process of economic and social recession which contrasts with the expansion period experienced during the early medieval centuries. In the fifteenth century the situation is aggravated for monasteries in rural areas due to the consolidation and growth of the cities. In that situation, some abbots tried to revitalize their communities by improving their infrastructures and trying to awaken the interest of pilgrims and visitors. In the following paragraphs we will see the essential role that advertising writing and more specifically the epigraphic Renovationes played in this propagandistic task.
\end{abstract}

\section{Keywords}

Epigraphy; inscription; epitaph; abbot; monastery; propaganda; mausoleum; renovatio.

* El presente trabajo se enmarca dentro del Proyecto "Corpus de inscripciones y textos hispano-latinos sobre arquitectura religiosa y civil altomedieval (s. V-X)" (acrónimo CITHARA). Ref. HAR2015-65649C2-1-P). Correo electrónico: agarm@unileon.es. ORCID: https://orcid.org/0000-0002-2717-8285. 


\section{Résumé}

La période médiévale tardive a signifié, pour certains grands monastères castillans, un processus important de récession économique et sociale qui contraste avec la période d'expansion vécue au cours des siècles du Haut Moyen Âge. Au XVe siècle, la situation est encore plus grave pour les monastères ruraux en raison de la consolidation et de la croissance des centres urbains. Face à cette situation, certains abbés essaient de revitaliser leurs communautés en améliorant leurs infrastructures et en cherchant à éveiller l'intérêt des pèlerins et des visiteurs. Ces lignes ont pour objet de démontrer le rôle essentiel que les écrits à visée publicitaire, et plus précisément les Renovationes épigraphiques, jouent dans ce processus.

\section{Mots Clé}

Épigraphie; Inscription; épitaphe; abbé; monastère; propagande; panthéon.

"Renovationes son aquellas inscripciones cuyos textos han sido redactados posteriormente sobre la base de otro anterior del que conservan lo esencial -notificación, intitulación y data-".

Dentro de esta tipología epigráfica podríamos incluir el conjunto de epitafios conservados en el baldaquino de la capilla mayor de la iglesia de San Salvador de Oña, al norte de la provincia de Burgos. Nos encontramos ante el panteón condal y real formado por un total de ocho sepulcros de madera, realizados a finales del siglo $\mathrm{XV}$, en el contexto del impulso renovador del abad fray Juan Manso².

El conjunto epigráfico de San Salvador de Oña es uno de los más significativos del panorama epigráfico español por varios motivos ${ }^{3}$ En primer lugar por tratarse propiamente de un panteón condal y real, donde la sola relevancia de los finados hace de la actividad epigráfica un recurso casi imprescindible 4 . En segundo lugar, porque no conservamos sepulcros originales sino que todos ellos fueron reelaborados y reubicados a finales de la Edad Media. En tercer lugar, cobra también importancia por la tradición histórica

\footnotetext{
García Lobo, “Las inscripciones medievales de San Isidoro de León”, pp. 371-398.

2 Se viene atribuyendo el traslado y la renovación de estos sepulcros al abad fray Juan Manso desde la época del Padre Flórez. Cf. Flórez, España Sagrada, p. 263. A principios del siglo XX, Gómez Barreda hizo una somera descripción de las obras llevadas a cabo por Manso destacando que una de ellas “... fué hacer los panteones de los reyes y colocarlos en ellos a el lado del altar mayor. Hizo assimismo la gran sillería de su coro, unida a los sepulcros y de una misma talla o filigrana". Con esta afirmación se consolida la discutible tradición anterior sobre el primitivo panteón regio disperso por el monasterio y aglutinado por este abad. Cf. BArreda, Oña y su Real Monasterio, p. 44. Sobre las reformas del siglo XV, vid. con carácter general Martín Martínez de Simón, "Las reformas del siglo XV en la iglesia del Monasterio de San Salvador de Oña”, pp. 634-647.

3 Una primera aproximación a este conjunto de Renovationes fue llevada a cabo por el Dr. Calleja Puerta para analizar los sepulcros nobiliarios y presentar su problemática. Cf. CALlEJA Puerta, "Seis renovationes sepulcrales del monasterio de San Salvador de Oña (Burgos)”, pp. 431-446.

4 Son muchos los autores que han puesto de relieve este valor atribuido a las inscripciones. Uno de los últimos en hacerlo y que reconoce esta tradición es el Prof. De Santiago. Cf. De Santiago Fernández, “Oraciones por la salvación del alma”, pp. 939-973, concretamente, p. 941.
} 
que su pasado ha marcado desde su fundación hasta nuestros días y que nos permite a los historiadores indagar en su pasado a través de la documentación, las crónicas, los epígrafes y las obras clásicas conservadas.

Por todo ello, nosotros, aquí y ahora, debemos comenzar recabando cualquier información o noticia sobre los enterramientos acaecidos en el monasterio antes de su renovación en el siglo XV, que nos facilite el motivo de tal decisión. Para ello son fundamentales los testimonios de autores como Berganza, Argaiz o Flórez cuyo rigor científico nos ha permitido recuperar tanto la noticia de las defunciones y su contexto histórico, como la ubicación y algunos detalles relacionados con los sepulcros $\mathrm{y}$, en su caso, de las primitivas inscripciones. Destacamos la importancia de todos estos eruditos pues, en la mayoría de los casos, suponen la única fuente conservada para rastrear las circunstancias mortuorias de los finados ya que sus sepulturas primitivas han desparecido sin que tengamos más noticia que los actuales sepulcros fechados en el siglo XV.

De forma más concreta analizaremos la contraposición que existe entre las noticias funerarias alusivas a los posibles epitafios originales y los Epitaphia sepulcralia hoy conservados en el monasterio -concretamente 8- y que fueron adecuados a los gustos, modas, tendencias e intenciones del autor que las encargó a finales de la Edad Media ${ }^{5}$.

A través de la comparación y análisis de estas dos realidades pretendemos hoy mostrar cómo la actividad publicitaria fue un recurso más al servicio abad -autor- en su intento por revitalizar y revalorizar el monasterio. Qué mejor forma para lograrlo que a través de la vanagloria de su pasado, utilizando como "vehículo" las inscripciones, y así lograr una "publicidad universal y permanente".

El corpus que vamos a presentar está compuesto por 12 inscripciones. De ellas se conservan únicamente 8 que se corresponden con ese periodo de renovación monástica de finales del S. XV que acabamos de mencionar.

\section{Breves consideraciones históricas}

El primitivo templo de San Salvador hunde sus raíces en el pasado románico, si bien ha sido evidenciada la existencia de un edificio anterior al de la fundación del siglo XI, cuyas pequeñas dependencias y recinto sacro debieron ocupar una situación próxima a la

\footnotetext{
Estos 8 epitafios serán los que incluyamos en el apéndice epigráfico final editados bajo las normas específicas de esta ciencia.

6 Desde mediados del siglo XX se viene atribuyendo a las inscripciones las cualidades de "publicidad, solemnidad y perduración" Cf. Gómez Moreno, El concepto de la Epigrafía, p. 93. Desde entonces se han querido matizar las connotaciones que ha de tener esa publicidad siendo un avance definitivo la propuesta del profesor Favreau en 1969: “...ce qui est écrit, en général sur une matière résistante, en vue d'une publicité universelle et durable" Cf. FAVREAU, "L'Épigraphie médiévale", p. 395. Sobre el proceso de evolución de la ciencia epigráfica y del concepto de inscripción en todo su conjunto remitimos a: GARCía LoBo, "La Epigrafía Medieval”, pp. 77-119, De Santiago Fernández, “La Epigrafía: Evolución conceptual y metodológica”, pp. 203-222, RodríGUez SuÁrez, “Un repaso a través de los conceptos de Epigrafía e inscripción”, pp. 147-154 e Pereira García, “La Epigrafía Medieval en España: Un estado de la cuestión”, pp. 267-302.
} 
cabecera de la actual iglesia ${ }^{7}$. Sin embargo, no está claro que este templo se corresponda con las escasas menciones que hay a la villa de Oña en el siglo X; villa que, por otra parte, ya gozaba de cierta entidad jurídica en la zona ${ }^{8}$. El templo románico documentado fue fundado en 1011 por el conde Sancho García, nieto del gran Fernán González ${ }^{9}$. Dicho conde había logrado aglutinar en este territorio buena parte de los apoyos con que contó en sus disputas dinásticas, lo que revertiría en agradecimiento hacia la zona a través de la dotación de nuestro monasterio ${ }^{10}$. Desgraciadamente, y como viene siendo habitual en muchos de estos templos burgaleses, es escasa la documentación que se conserva para el periodo fundacional ${ }^{11}$. Lo que sí sabemos es que en origen pudo tratarse de un monasterio dúplice o que al menos existió una comunidad masculina y una femenina ${ }^{12}$. Pronto pasó a estar formado únicamente por un grupo de monjes de la órbita de Cluny debido al nuevo impulso que Sancho III quiso darle ${ }^{13}$. En este periodo llegan al monasterio las mayores influencias y los más eficaces benefactores; es el momento de su desarrollo como panteón condal y real. Bien es cierto que se trataba de mantener las intenciones que el conde Sancho García y su mujer habían reflejado en el documento fundacional ${ }^{14}$.

Junto a la figura de estos grandes monarcas destaca la del abad san Íñigo ${ }^{15}$. Traído a Oña desde San Juan de la Peña por Sancho el Mayor, pronto se convirtió en un dirigente monástico a la altura intelectual -e histórica- del propio Domingo Manso en Silos $^{16}$. Su carisma evitó la pérdida de influencia del monasterio durante el siglo $\mathrm{XI}^{17}$.

\footnotetext{
Sobre el origen del monasterio, vid. con carácter general Reyes TélLez, "Los orígenes del Monasterio de San Salvador de Oña", pp. 32-51.

8 Ibidem, pp. 38-39.

9 Pérez de Urbel, El Condado de Castilla, p. 122.

10 Reyes Téllez, "Los orígenes del Monasterio de San Salvador de Oña", p. 35.

11 Por ello, es frecuente que se haya recurrido a la leyenda para generar un pasado grandioso. En Oñaadvierte Flórez-, el nombre del monasterio y del lugar, no provienen de donde refiere la Crónica General, en donde se asegura que el conde don Sancho, tras dar muerte a su madre, mandó fundar un monasterio al que, arrepentido, puso el nombre de la difunta. Cf. Flórez, España Sagrada, p. 252.

12 Sobre la controvertida duplicidad de Oña cf. Rodríguez MuÑoz, "Iglesias Románicas Palentinas", pp. 27-126, concretamente p. 40 y Reyes Téllez, "Los orígenes del Monasterio de San Salvador de Oña", p. 49.

13 Sobre la influencia cluniacense en Oña y su repercusión en el ámbito político y artístico Cf. SENRA GABRIEL Y GALÁN, "La irrupción borgoñona en la escultura castellana de mediados del S. XII", pp. 35-51 e ID., "La implantación del románico en el Monasterio de San Salvador de Oña (siglos XI y XII)", pp. 568-575. Sobre la observancia a una "Regula Communis" anterior a la implantación benedictina, vid. con carácter general LinAJE CONDE, "De los monjes a los frailes. Notas sobre la implantación de la vida religiosa en el territorio castellano-leonés", pp. 263-274. En relación a la controversia sobre la mayor o menor influencia de la órbita de Cluny sobre Oña Cf. Maté SAndornil, "El monasterio de Oña en el entono de Cluny", pp. 157-158.

14 BAZtÁn, "El monasterio de San Salvador de Oña y la tumba de Don Sancho el Mayor, rey de Navarra", p. 107 y FaCi LaCasta, "Sancho el Mayor de Navarra y el monasterio de San Salvador de Oña”, pp. 299318. Sobre el documento fundacional de Oña y su particular idiosincracia Cf. ZabalZa DuQue, "Hallazgo del documento original de la fundación del moansterio de Oña”, pp. 325-332.

15 San Íñigo, abad de Oña entre 1178 y 1192. Colombís, “Oña”, p. 1612.

16 Sobre el gobierno de san Íñigo en Oña, vid. con carácter general: LóPEZ SANTIDRÁN, "San Íñigo, abad de Oña", pp. 164-177.

17 Sobre el patrocinio de Sancho III a Oña y su abad san Íñigo cf. De LA Fuente, "El monasterio de Oña y su panteón regio", pp. 194-207, concretamente, pp. 195-197.
} 
Estamos ante el primer gran momento del cenobio oniense que, como veremos, tiene una enorme transcendencia en la actividad epigráfica primitiva ${ }^{18}$. Durante esta etapa la relevancia de Oña llegó a ser tal, que sus intereses chocaron con los del episcopado burgalés ${ }^{19}$. Su supremacía aumentó en el siglo XII llegando a regular las relaciones entre Castilla y Navarra y terminó erigiéndose como principal nexo vertebrador entre estos dos poderes. Es también un periodo de especial trascendencia dentro del románico burgalés ${ }^{20}$. Caracterizado por la creación y dotación de iglesias y monasterios; muchos de los cuales estuvieron bajo la órbita de influencia de San Salvador ${ }^{21}$. La estabilidad política y la proliferación de las peregrinaciones jacobeas favorecieron aun más las prerrogativas de los grandes templos, entre los que Oña había de jugar un papel más que destacado ${ }^{22}$. La dinámica de esta centuria, desde un prisma socio-económico, se caracteriza por la reagrupación de pequeñas iglesias y pequeños centros monásticos en torno a los grandes monasterios. Es sin duda el gran momento de nuestro templo ${ }^{23}$. El siglo XIII representa un panorama distinto ${ }^{24}$. Tras la unificación de los reinos y la centralización del poder, tiene lugar el aumento de la autoridad regia y el desarrollo de la ciudad de Burgos ${ }^{25}$. Todo ello se tradujo en una importante pérdida de la capacidad económica y de la influencia de este cenobio ${ }^{26}$. El resultado-diríamos- es el comienzo del fin de la hegemonía de Oña ${ }^{27}$.

\footnotetext{
18 Aunque las referencias epigráficas conservadas en Oña son inexistentes, pensamos que la actividad constructiva y escrituraria no debió distar mucho de la ocurrida en otros cenobios burgaleses como Santo Domingo de Silos. Remitimos al brillante trabajo del profesor García Lobo para explicar la operativa de estos talleres artísticos y su irrupción en la epigrafía. Cf. GARCíA LoBo, "Las "explanationes" del claustro de Silos: nueva lectura", pp. 483-494.

19 AA.VV., Enciclopedia del Románico, p. 1331 e Sánchez Domingo, "Conflictos de jurisdicción con la mitra burguense", pp. 408-441.

20 Vid. con carácter general Senra Gabriel y Galán, "Arquitectura en el monasterio de San Salvador de Oña durante los siglos del románico”, pp. 483-507.

21 Sánchez Domingo, "Dominio y jurisdicción de la Abadía de Oña".

22 Sobre el panorama político y social burgalés en este periodo. Cf. GARCía de CoRTAZAR, "Organización social del espacio burgalés en la Alta Edad Media”, p. 21.

23 Sobre la organización eclesiástica de Castilla cf. Corullón PARedes, "Monacato y organización eclesiástica en la Castilla altomedieval”, pp. 587-599. Allí la prof. Corullón resalta la transformación de la estructura eclesiástica de la provincia nacida a partir de los eremitorios, dando lugar a multitud de monasterios en los primeros compases del S. X, para quedar bajo la influencia de los grandes linajes y los grandes monasterios a lo largo del S. XII.

${ }^{24}$ Como es lógico, desde el periodo fundacional hasta la crisis del siglo XIII la fábrica del monasterio sufre una serie de transformaciones fruto de la impronta que el devenir histórico había dejado en sus estructuras. Vid. con carácter general Palomero Aragón, "El monasterio de San Salvador de Oña: La iglesia y entorno, su evolución y cambios desde el siglo XI al XIII", pp. 362-397.

25 En relación a la importancia político-territorial que había adquirido Oña hasta este momento Cf. SÁnchez Domingo, El régimen señorial de Castilla Vieja. La casa de los Velasco, p. 70.

26 Sobre la transformación del Oña a partir del siglo XIII Cf. SuÁrez Bilbao, "El monasterio de Oña en tiempos de los Trastámara", pp. 136-140.

27 Viñuales Ferreiro, "Economía del dominio monástico de San Salvador de Oña en la Baja Edad Media", pp. 396-407.
} 
A lo anterior hemos de añadir la incidencia del cambio en la estructura social y la caída del benedictinismo ${ }^{28}$. El estamento eclesiástico se divide y mientras que las clases más bajas de éste ven diluida su trascendencia, el alto clero cobra un enorme protagonismo junto con las nuevas clases altas urbanas. Además, en el caso de Oña, habría que sumar la aparición de Frías como villa real. Ésta le disputó a nuestro cenobio alguno de sus más importantes bienes patrimoniales, hiriendo gravemente la hacienda oniense ${ }^{29}$. Todo este panorama está aderezado por las continuas guerras civiles que tienen lugar entre los años finales de este siglo y el primer cuarto del S. XIV ${ }^{30}$. El resultado fue el auge en el siglo XIV de la nobleza que vio en los dominios monásticos una oportunidad para aumentar su capital, impulsada por la política territorial que Alfonso XI ejerció en la zona ${ }^{31}$.

En resumen, este templo representa el paradigma de lo grandes monasterios Burgaleses ${ }^{32}$. Destacado por su enorme importancia y actividad durante los siglos alto y plenomedievales, su fama e influencia fueron cayendo en el periodo bajomedieval debido a las fuertes crisis económicas y a la disminución de privilegios que traía consigo la pérdida de apoyo regio que paulatinamente fue aconteciendo.

\section{Los epitafios renovados}

Sin embargo, y como ya adelantábamos al comienzo de este trabajo, el acontecimiento más importante en la historia oniense desde la perspectiva epigráfica es su conformación como panteón regio ${ }^{33}$. Es sabido que la actividad epigráfica más prolífera es la relacionada con la muerte ${ }^{34}$. Y estas inscripciones funerarias gozan aun de mayor relevancia cuando los finados son personajes ligados al poder.

La epigrafía funeraria tienes varias causalidades. Por un lado, elegido el recinto sagrado para el descanso eterno del difunto, las inscripciones garantizan el recuerdo de la obliga-

\footnotetext{
28 Suárez Bilbao hace referencia a la multiplicidad de factores que influyeron en esta decadencia poniendo de relieve, en el caso de Oña, el especial impacto que tuvo el auge de los Velasco y de la nobleza de las Merindades en general. Cf. SuÁrez Bilbao, El monasterio de Oña en tiempo de los Trastámara, p. 136.

29 Martín Viso, Poblamiento y estructuras sociales en el norte de la Península Ibérica. Siglos VI-XIII, pp. 296-297.

30 Ruiz, "El siglo XIII y primera mitad del siglo XIV", p. 101.

31 Suárez Bilbao, El monasterio de Oña en tiempo de los Trastámara, p. 137.

32 Vivancos Gómez, "Problemática general de los monasterios benedictinos en la Plena Edad Media", pp. 599-607.

33 Sobre esta primera etapa de formación del panteón en la Alta Edad Media vid. con carácter general Vivancos Gómez, "En la vida y en la muerte. Estancias y sepulcros reales en San Salvador de Oña en época altomedieval", pp. 13-42.

34 "Pocas, por no decir ninguna, realidad humana ha merecido tanta reflexión y ha producido tanta bibliografía, y tanta Epigrafía, como la Muerte". Con estas palabras inicia el prof. García Lobo su artículo sobre la importancia de las inscripciones para la perpetuación de la memoria de los difuntos y toda la filosofía mortuoria. Cf. GARCíA LOBO, "El difunto reivindicado a través de las inscripciones", pp. 171-198.
} 
toriedad o conveniencia de las oraciones de los fieles, según los casos ${ }^{35}$. Por otro lado, los deudos, a través de estos textos donde se resaltan las virtudes o hazañas del difunto, tratan de buscar su propia vanagloria utilizando la inscripción como reclamo publicitario para su proyección o promoción personal ${ }^{36}$. De igual modo las principales dignidades de iglesias, monasterios y catedrales utilizaban - aún hoy se utiliza- la significación de tales personajes para ensalzar la historia de sus templos, fomentar las peregrinaciones y donaciones o con fines pedagógicos mostrando ejemplos de vida santa ${ }^{37}$.

Bien podríamos decir que todo este compendio de intenciones se da en Oña. Sin embargo, los hábitos comunicativos siempre responden a los gustos y preferencias de la sociedad que los produce. En nuestro caso, esto nos obliga a diferenciar, al menos, dos etapas según nos refiramos a los epitafios originales o sus renovaciones del siglo XV. Los originales de los siglos XI y XII -sus textos- guardan una estrecha relación con el interés inicial de Sancho III por ensalzar el cenobio y crear en él un panteón regio ${ }^{38}$. El autor de las inscripciones en este periodo busca, a través de epitafios extensos y muy elaborados, reivindicar la figura del finado ${ }^{39}$. En esta primera época el conjunto de sepulcros y lápidas debían estar ubicados en el claustro y Yepes lo describe de la siguiente manera:

"Así digo que en el claustro principal de esta casa están enterrados muchos varones excelentes en carneros y arcas de piedra labradas muy curiosamente con sus armas y letreros, que servirán de elogios y vidas breves para que sus descendientes conozcan cuán valerosos fueron sus progenitores" $"$.

\footnotetext{
35 El culto a los difuntos en los monasterios medievales es un aspecto de sobra conocido, especialmente en la orden benedictina. Vid. con carácter general LinAJE CONDE, Los orígenes del monacato benedictino en la Península Ibérica, pp. 394-395.

36 Sobre la autopromoción del difunto a través de los textos epigráficos Cf. De SAntiago Fernández, "El programa iconográfico del monumento sepulcral de don Martín Vázquez de Arce (El Doncel de Sigüenza)", p. 329 .

37 Buena parte de estas intenciones se aúnan en el epitafio de santo Domingo de Silos. Su autor, el abad Fortunio, pretendió divulgar las virtudes del clérigo con la intención de, a través de su invocación, fomentar las peregrinaciones, así como instruir a la comunidad de monjes hacia una de vida santa como la que Domingo ejerció. Sobre la funcionalidad de las inscripciones cf. GARCía LoBo y Martín LóPez, "La escritura publicitaria en la Edad Media. Su funcionalidad", pp. 142-144 y García Morilla, "De la funcionalidad de las inscripciones. El caso de monasterio de Santiago de Peñalba (León)", pp. 273-293.

38 No es este el momento de analizar pormenorizadamente los textos originales. Su particular problemática superaría holgadamente los límites de este trabajo pero conviene advertir sobre su controversia. Para un acercamiento más detenido remitimos a CAlleja PuerTa, "Seis renovationes sepulcrales del monasterio de San Salvador de Oña (Burgos)".

39 Sobre el autor de las inscripciones funerarias Cf. García Lobo y Martín López, "La publicidad en el Císter", pp. 47-66, concretamente p. 48 y GARCía LoBo, "El difunto reivindicado a través de las inscripciones".

40 De Yepes, Crónica general de la Orden de San Benito, p. 435) y García Morilla, Antonio de Yepes y la Epigrafía Medieval, p. 61.
} 
Qué duda cabe que la identificación más ordinaria de los cuerpos se hacía a través de las inscripciones, tal y como señala Yepes. Un buen ejemplo es la Chronica sepulcral -hoy desaparecida- del conde don Sancho, fundador del monasterio, cuyo texto tomamos de Berganza ${ }^{41}$ :

"Sanctius iste Comes, populis dedit optima iura: Cui Lex Sancta Comes, ac Regni maxima cura. Mauros destruxit, ex tunc Castella reluxit; Haec loco construxit, istinc normam quoque duxit: Tandem vir fortis, devictus pondere mortis, Pergens ad Christum, mundum transposuit istum. Comes iste post multas victorias habitas de Sarracenis quievit in pace sub Era MLV. Nonis Februarii" $" 42$.

El epígrafe recoge las numerosas bondades, tanto bélicas como morales, del conde ${ }^{43}$. Sobre todas ellas destaca la fundación del monasterio e iglesia de Oña. Se muestra al finado, por tanto, como un ejemplo de vida; virtudes propias de quien quiere alcanzar la vida eterna a través de los méritos terrenales. Por el propio cariz de la redacción, ésta pudo ser encargada por el abad. Según Berganza, la lápida debió estar situada en la iglesia, próxima a la puerta principal. Sin duda, un lugar de fácil acceso al lector cuya atención, nada más entrar en el templo, había de ser conducida hacia el sepulcro y su inscripción para admirar los merecimientos de su fundador y tomarlos como ejemplo ${ }^{44}$. Casi nada tiene que ver con este epitafio conservado actualmente en San Salvador para nuestro conde fundador:

\footnotetext{
41 Berganza, Antigüedades de España, p. 310.

42 "Este conde Sancho concedió a sus poblaciones excelentes fueros; tuvo por compañera la Ley de Dios y su mayor preocupación fue su reino; destruyó a los mauros y, desde entonces, brilla Castilla. Construyó este lugar y lo dotó de regla: finalmente, aunque hombre valeroso, cayó vencido por el peso de la muerte. Emprendiendo el camino hacia Cristo, abandonó este mundo. Este conde tras innumerables victorias contra los Sarracenos, descansó en paz, el día 5 de febrero de 1017”.

43 Como ya hemos insinuado en algunas ocasiones, es ciertamente complicado asegurar si nos encontramos ante el obituario o necrologio del monasterio, si se trata de una tradición histórica o si verdaderamente es la interpretación de los primitivos epitafios. Bien es cierto que es frecuente encontrar algunas de estas crónicas o epitafios necrológicos próximos a los lugares de enterramientos con la clara intención de preservar la memoria para la salvación del alma del difunto y que, como decíamos más arriba, la identificación ordinaria de los sepulcros se hacía a través de las inscripciones. Podría ser éste el caso que nos compete. O bien podría tratarse de una fabulación intencionada de las crónicas, redactadas tiempo después de los hechos, para devolver la gloria al templo y sobre la que se reconstruiría, siglos después, el panteón del siglo XV. Cf. Martín LóPez, "La salvación del alma a través de las inscripciones medievales”, pp. 255 279 y De Santiago Fernández, "Oraciones para la salvación del alma”.

44 Yepes en su edición se limita a traducir los méritos enumerados en la edición del epitafio de Berganza. Se entretiene en desarrollar su genealogía, así como en explicar el especial interés que tuvo en la fundación de esta casa de Oña. De la misma forma se incluye entre sus méritos el hecho de ser el responsable de la llegada de san Íñigo a Oña. Cf. De YePEs, Crónica general de la Orden de San Benito, p. 427 y GARCía Morilla, Antonio de Yepes y la Epigrafía Medieval, pp. 127-128.
} 


\section{FIGURA 1}

\section{Renovatio epitafio del donde D. Sancho. (García Morilla)}

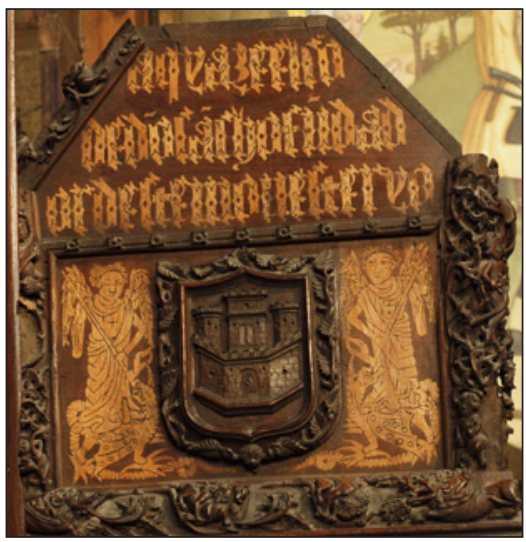

"Aqui yace el conde don Sancho fundador deste monesteryo".

A estas diez palabras se ciñe el necrologio que recuerda hoy la memoria de don Sancho. Situado en la parte inferior de la tapa del sepulcro de madera y realizado mediante la técnica de la taracea, este somero texto había de suplir a la elaborada crónica del siglo $\mathrm{XI}^{45}$. Es evidente que ni su funcionalidad ni su intención eran la misma. Ahora, a finales del S. XV, la historia oniense era de sobra conocida y únicamente era necesario recordar las glorias pasadas. Epigráficamente se haría a través epitafios con el nombre de sus personajes más ilustres, y de ellos se destacaría la acción o significado que más importancia tuviera para con el templo.

En este sentido, el emplazamiento también juega un papel destacado. En primer lugar, recordemos que todo el conjunto está situado en un baldaquino próximo al altar; lugar de tránsito habitual de los fieles ${ }^{46}$. La estructura y la ornamentación actúan, a su vez, como reclamo publicitario y ayudan a la inscripción en su misión de publicidad universal y permanente ${ }^{47}$. Desde el punto de vista epigráfico también se repite un esquema similar. Textos de breve extensión donde se consignan los datos esenciales del finado. Se trata de reconocer a través de unas pocas palabras a los personajes y la impronta que dejaron en la historia oniense. De este modo, se logra la uniformi-

\footnotetext{
45 Para más información al respecto Cf. FugA, Técnicas y materiales de arte.

46 Cuando reflexionábamos sobre la funcionalidad de las inscripciones medievales señalábamos que "también influye en el éxito de esta comunicación la ubicación y legibilidad que tengan los epígrafes". Cf. García Morilla, "De la funcionalidad de las inscripciones. El caso de monasterio de Santiago de Peñalba (León)”, pp. 276-277.

47 Definida por el profesor Favreau, y actualmente reconocido por todos los estudiosos de la Epigrafía medieval, la inscripción es un testimonio escrito en orden a una publicidad universal y permanente. $\mathrm{Cf}$. FAVREAU, Epigraphie médiévale, p. 31.
} 
dad en el conjunto sin que unos epígrafes sobresalgan sobre otros ni en extensión ni en méritos. Esta manera de ejecutar el panteón real nos permite sostener nuestro argumento sobre la principal misión -funcionalidad- de este conjunto epigráfico; argumento revitalizador y publicitario de la historia de San Salvador ${ }^{48}$.

Siguiendo nuestro recorrido, encontramos otro sepulcro de madera. Éste se encuentra en el lado de la Epístola, a continuación del anterior, y es atribuido a doña Urraca, mujer del conde Sancho García. La noticia más antigua sobre su óbito la encontramos en Yepes quien pudiera haberse inspirado en el epitafio original para redactar las siguientes líneas:

"La segunda arca, junto a esta primera, guarda los huesos de la serenísima Señora la condesa doña Urraca, mujer del dicho señor conde don Sancho de Castilla, en la cual hubo el dicho señor conde un hijo y tres hijas; conviene a saber, al infante don Carlos, que fue muerto a traición en la ciudad de León; la mayor de las hijas llamaron doña Mayor, que fué casada con el rey D. Sancho el Magno, y Mayor por otro nombre, y a la segunda llamaron doña Teresa, que fué casada, según algunos dicen, con el rey D. Bermudo de León, y a la tercera fué la dicha doña Trigida, virgen, que esta dicha señora condesa doña Urraca pasó de este mundo al reino de los cielos a 20 días del mes de mayo, año del Señor de $1025 \% 49$.

Por su parte, el sepulcro renovado reza así:

FIGURA 2.

Renovatio del Epitaphium sepulcrale de doña Urraca. (García Morilla)
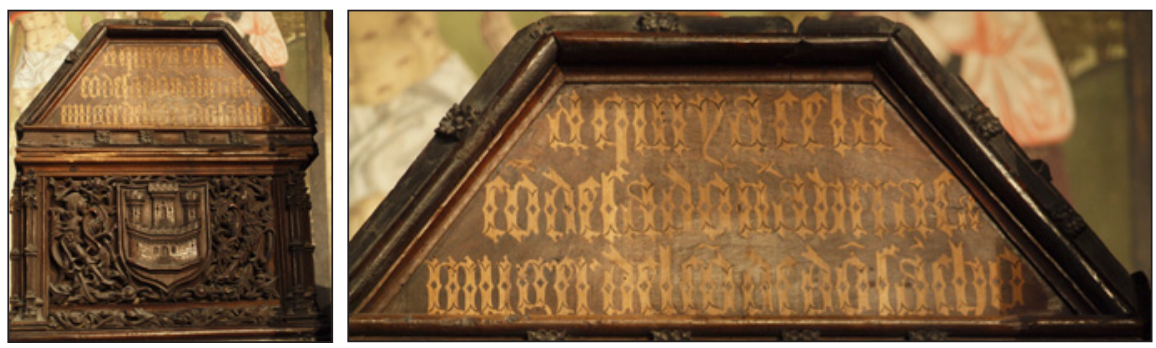

“Aquí yace la condesa donna Urraca, muger del conde don Sancho”.

\footnotetext{
48 A propósito de las inscripciones funerarias, los Prof. García Lobo y Martín López señalan: “en ellas, además de la noticia de la muerte o el enterramiento del difunto, el autor suele cantar y destacar algunas de las cualidades que le adornaron en vida". Cf. GARCía LoBo y Martín López, "La escritura publicitaria en la Edad Media. Su funcionalidad", p 133.

49 De Yepes, Crónica general de la Orden de San Benito, p. 428 y García Morilla, Antonio de Yepes y la Epigrafía Medieval, p. 128.
} 
No es casualidad que al situar este arca junto al de su marido prime su relación con éste en la redacción del epitafio moderno. Asociada por algunos a la familia Salvadores ${ }^{50}$ y por otros a la de los Banu Gómez ${ }^{51}$, su nombre siempre ha estado vinculado al de su marido y al de su hija doña Mayor, mujer de Sancho III.

Algo similar ocurre con el epitafio del conde don García. Su epitafio original, extenso y del que conservamos copia literaria, relata la trágica muerte del joven. En esta ocasión es Argaiz de quien tomamos la noticia:

"Hic aetate puer Garsias Absalon alter fit cinis: Illud erit, qui gaudia mundi quaerit. Mars alter durus bellis erat ipsi futurus; sed fati serie prius occubuit. Hic filius fuit Santii istius comitis, qui interfectus fuit prodisione a Gundisavldo Munione et a Munione Gustio, et a Munione Rodriz et a multis aliis, apud Legionem civitatem" 52 .

Además, Argaiz nos informa de la ubicación de este primitivo epitafio -la inscripción se encontraba a los pies de la iglesia-y de la materialidad del mismo -cincelada en un arca de piedra labrada-. Del mismo modo incluye datos significativos de cómo accedió al texto:

"Tengo una curiosa antigüedad en el Archivo de Oña, no vista hasta oy, que es el epitafio, que luego traxeron de León el cuerpo, le pusieron al Infante en la Tumba de piedra, donde le dieron sepulcro a la puerta de la Iglesia, en compañía de sus padres: y algún curioso, temiendo que cuando los metiera dentro del templo se perdieran, lo sacó y copió" 53 .

Estas palabras son muy significativas por varias razones. En primer lugar, al plantear la hipótesis de que alguien tuviera miedo a que se perdiese, pensamos que de sus palabras se colige que él sí vio el epitafio original. Por otro lado, no sabemos si estamos ante una copia del texto - como dice Argaiz- o ante la posible minuta en papel del texto que debía trasladarse al sepulcro. Además, también podemos deducir que los epitafios debían grabarse con posterioridad a su traslado a Oña y una vez que los sepulcros se encontraban debidamente finalizados. De aquí también se desliza la idea de que Oña

50 Es Pérez de Urbel quien tradicionalmente ha asociado el nombre de la condesa Urraca a la familia Salvadores, una de las más importantes en la Castilla del siglo XI. Cf. Pérez de Urbel, Historia del Condado de Castilla, p. 895.

51 Esta idea, más moderna y razonada, es defendida, entre otros, por Martínez Díez. Cf. MarTínez Díez, El condado de Castilla (711-1038). La historia frente a la leyenda, p. 638.

52 Argaiz, La Soledad Laureada, pp. 180-181. Podríamos traducirlo así: "Aquí se vuelve ceniza García, niño de esta edad; estará allá el que busca los goces del mundo. Estaba llamado a ser, cual otro Marte, un guerrero duro; pero murió en tierna edad por permisión de la divinidad. Fue hijo de este conde Sancho y fue matado a traición por Gonzalo Muñoz, por Munio Gustio, por Munio Rodríguez, y por otros muchos en la ciudad de León. Era el año1028". Agradecemos al profesor García Lobo que nos haya ayudado en la traducción e interpretación de este texto.

53 Ibidem, p. 180. 
pudiera contar con un taller epigráfico para estas labores ${ }^{54}$. Berganza, que también recoge este texto, admite estar copiando las inscripciones de un libro; quizá porque no visitó el claustro o porque en época del autor ya no se conservaban ${ }^{55}$.

Por lo que respecta a la actualización de este sepulcro y epitafio, nos encontramos con la misma dinámica de los ejemplos anteriores. Un texto verdaderamente breve de apenas once palabras:

Figura 3.

\section{Renovatio del epitafio del conde don García (García Morilla)}

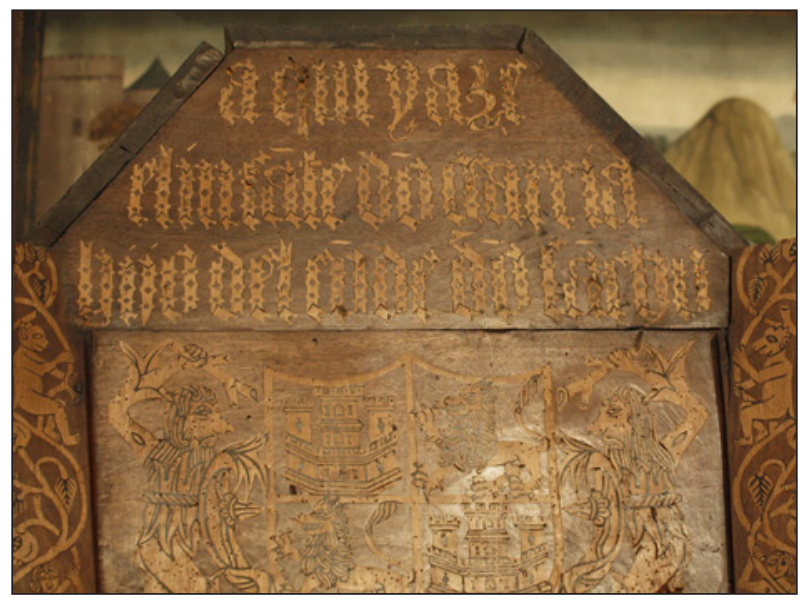

"Aqui yace el III conde don Garcia hijo del conde don Sancho".

Al igual que su madre, los datos recogidos en este epitafio se limitan a la filiación paterna. Casi diríamos que su presencia se justifica únicamente por ser hijo del gran conde fundador y por la transcendencia para el panteón condal de albergar a un nuevo personaje de este linaje. Limitar los datos epigráficos a la filiación tiene mucho que ver con la falta de espacio - en el arca- y, por consiguiente, con la necesidad de buscar un único dato que permita "localizar" históricamente al personaje. Un conde muerto a tan temprana edad apenas tiene hechos en su haber que merezcan tal conmemoración histórica, sino es su genealogía. Respecto a su padre, García representa un personaje de menor importancia diríamos. En el siglo XV, este conde era considerado un personaje de segundo orden, muy al contrario que en el siglo XI, cuando su valentía y la traición sufrida en su muerte eran atributos dignos de ser admirados y reconocidos por todo aquel que presentase sus respectos ante su sepultura en Oña. Al final de la Edad Media, estos hechos han ido cayendo en el

\footnotetext{
54 Sobre los talleres epigráficos de la provincia de Burgos Cf. García Morilla, "Talleres, scriptoria y pequeños centros. La producción epigráfica en la provincia de Burgos”, pp. 145-193

55 Berganza, Antigüedades de España, p. 314.
} 
olvido; de ahí que no se haya puesto, como sí ocurría en el epitafio original, ningún dato alusivo a su traumática muerte. Es necesario recordar que durante la Baja Edad Media los méritos acumulados durante una vida digna y valerosa son el aval necesario para alcanzar la vida eterna, olvidándose en cierta manera las virtudes con que cuenta un niño por el mero hecho de no haber corrompido su vida en tan tierna infancia ${ }^{56}$.

El cuarto y último sepulcro del lado de la Epístola alberga los restos de los infantes Felipe y Enrique, hijos de Sancho IV y María de Molina. El hecho de que ambos infantes compartan arca ya es significativo de la relevancia que se dio a ambos en el siglo XV. Únicamente se trata de recoger la memoria de que fueron enterrados en Oña y que aun se custodian sus restos en San Salvador. De nuevo se trata de restos con un valor cuantitativo, que engrosen el panteón real. La noticia de Yepes al respecto del enterramiento de estos infantes no es muy descriptiva:

"En la cuarta tumba están los huesos de los serenísimos infantes, hijos del rey D. Sancho IV, rey de Castilla y de León, el cual mandó edificar la capilla de Nuestra Señora de esta casa para el enterramiento de los señores reyes, que después por mayor honra fueron trasladados a este lugar, en que están ahora"s7.

El epitafio compartido actual reza así:

FiguRA 4.

\section{Renovatio del $E$. Sepulcrale de los infantes Felipe y Enrique (García Morilla)}

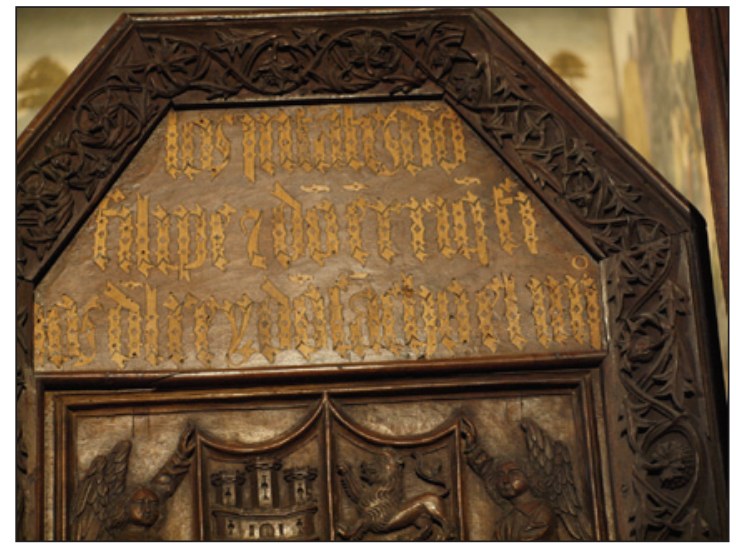

"Los infantes don Filipe y don Enrique fijos del rey don Sancho el IIII" ".

\footnotetext{
56 Sobre el cambio de mentalidad que se produce en la Baja Edad Media en torno a la virtud y la muerte remitimos a los dicho en: GARcía Morilla, “QQuién publica mensajes en las Catedrales?”, pp. 313-325, concretamente pp. 314 y 315.

57 De YePes, Crónica general de la Orden de San Benito, p. 429 y García Morilla, Antonio de Yepes y la Epigrafía Medieval, p. 129.
} 
Mismo argumento que hemos visto en lo ejemplos anteriores. Filiación paterna para identificar a los personajes. En este caso, y a pesar de que su padre, el rey Sancho IV, no fue enterrado en Oña, se hace mención a su figura para engrandecer, publicitariamente, la historia de templo, amén de ayudar a reconocer más rápidamente a los finados.

Aunque no es lugar aquí y ahora de adentrarse en la controversia de sí los infantes fueron enterrados o no originariamente en Oña, lo cierto es que sí pensamos que su inclusión a finales de la Edad Media tiene mucho que ver con la intencionalidad del autor de las Renovationes del siglo $\mathrm{XV}^{58}$. En alguna ocasión nos hemos planteado la posibilidad de que los sepulcros recojan los restos de otros finados en Oña cuya identificación en el siglo XV se relacionó de forma fortuita o intencionada con la de los infantes cuya tradición histórica se entroncaba con el templo burgalés. No hay duda del prestigio que suponía para cualquier iglesia o monasterio el hecho de ser elegido como lugar de enterramiento por cualquier miembro de la familia real ${ }^{59}$. En este caso, además, se atrae hacia Oña, aunque sea de forma indirecta, a Sancho IV. Con esta redacción del texto, el autor consigue vincular a tres miembros de la realeza al panteón aunque uno de ellos no fuese enterrado allí. Así se aumenta la efectividad del abad Manso a la hora de revitalizar la tradición oniense a través de la publicidad epigráfica ${ }^{60}$. De esta manera se garantiza una de los axiomas de una inscripción: "llegar a un público lo más amplio posible" ${ }^{\text {" }}$. Pensamos que ésta es la máxima que debió figurar en la cabeza de nuestro abad a la hora de concebir los letreros que había de acompañar a las ornamentadas arcas de madera del panteón.

Diferente es lo que ocurre en los sepulcros del lado del Evangelio. En este caso se trata de personajes más conocidos; publicitariamente más atractivos diríamos. Los cuatro sepulcros están dedicados a personajes especialmente vinculados con la historia de Castilla $^{62}$. En el primero de ellos encontramos a Sancho $\mathrm{II}^{63}$ :

\footnotetext{
58 La sepultura del infante Felipe se la disputan el monasterio de las Huelgas de Burgos y el monasterio de las Dueñas de Santa Clara de Allariz. Por su parte, el infante Enrique podría estar en la capilla mayor del convento de los dominicos de San Ildefonso de Toro, siguiendo la tradición del testamente de su madre María de Molina. Cf. Del Arco, Sepulcros de la Casa Real de Castilla, pp. 270-272.

59 Orlandis Rovira, "Sobre la elección de sepultura en la España medieval", pp. 5-49.

60 Hacemos nuestras las palabras del Prof. de Santiago cuando dice: "Es evidente que el uso de la escritura está en función de su utilidad en una sociedad dada. Las inscripciones están inmersas en una sociedad concreta, con unos usos culturales y religiosos determinados que, sin duda, no sólo influyen, sino que podríamos decir determinan el resultado final del epígrafe". Cf. De SAntiago Fernández, "Inscripciones en lipsanotecas y tapas de altar catalanas de los siglos X-XII. Su origen y función”, pp. 35-62, concretamente, p. 36. ${ }_{61}$ El profesor Favreau ya señalaba en 1979 que "las inscripciones se materializaban para llegar a un público lo más amplio posible" y qué duda cabe que ello se consigue a través de unos caracteres de gran tamaño y legibles, de soportes duraderos y, lógicamente, a partir de la propia información que proporciona el texto. Cf. Favreau, Les inscriptions médiévales, p. 272. Por su parte, El profesor García Lobo, al hablar del destinatario de las inscripciones les otorga tres características fundamentales: "indefinición, multiplicidad y trascendencia". Cf. García LoBo, "La Epigrafía Medieval. Cuestiones de método", p. 90. 62 Decimos "dedicados" para evitar la controversia de si se trata de sepulcros verdaderos, cenotafios o falsos. Insistimos que lo que aquí nos interesa es la comparación y relevancia de la actividad epigráfica en torno a un panteón real.

63 Elorza, Castillo y Negro, El Panteón Real de las Huelgas de Burgos. Los enterramientos de los reyes de León y Castilla, p. 54.
} 
FIGURA 5.

Renovatio del E. Sepulcrale del rey Sancho II de Castilla. (García Morilla)

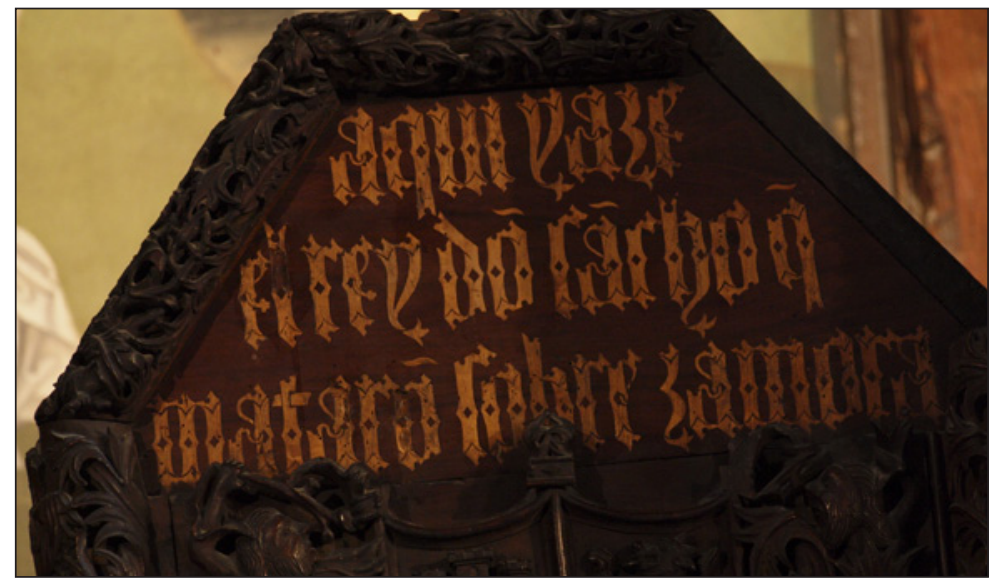

"Aqui yace el rey don Sancho que mataron sobre Zamora":

Aquí ya se olvidan los datos de filiación y se utiliza el hecho más relevante de la vida del monarca para identificarlo. De los "sanchos" éste siempre será recordado por la traición sufrida a manos de su hermana doña Urraca en Zamora donde Bellido Dolfos le dio muerte ${ }^{64}$. Así lo describía la Chronica sepulcral, recogida por Berganza, que debía decorar el sepulcro original del rey ${ }^{65}$ :

"Sancius forma Paris, et ferox Hector in armis, clauditur hac tumba, iam factus pulvis, et vmbra: femina mente dira, soror, hunc cita expoliavit. Iure quidem dempto, non flevit, fratre perempto. Rex iste occisus est proditore consilio sororis suae Urracae apud Numantiam Civitatem per manum Belliti Adelfis magni traditoris, in Era M. C. X. Nonis Octobris, rapuit me cursus ab horis " 66 .

Como podemos apreciar, en ambos casos se hace hincapié en el suceso histórico más destacado de su vida. El autor de la renovación simplifica el hecho resaltando los datos

\footnotetext{
64 Vid. con carácter general. BAutista PÉREz, "Sancho II y Rodrigo Campeador en la Chronica Naierensis". 65 Berganza, Antigüedades de España, p. 435.

66 "Sancho, comparable por su belleza a Paris y por su valentía con las armas a Héctor, está recluido en esta tumba, reducido ya a cenizas y a una sombra. Su hermana, mujer de corazón despiadado, le quitó la vida, contra todo derecho, no lloró al hermano muerto. Este rey fue matado por la intriga traidora de su hermana Urraca en la ciudad de Numancia (Zamora) por la mano de Bellido Adolfo, el gran traidor. El siete de octubre del año 1072 me arrebataron del rumbo (normal) del tiempo".
} 
suficientes para que el lector reconozca al finado. Esta identificación se basa en mostrar la dignidad del finado - rey- y en el principal hito de su reinado - que mataron sobre Zamora-. El autor de la inscripción simplemente trata de diferenciar a este monarca de otros del mismo nombre. No hace falta ensalzar más su figura; estamos ante uno de los grandes monarcas castellanos.

En la misma línea pero aun más simple es el arca de Sancho Garcés III el Mayor de Navarra. Dentro de este conjunto de renovaciones quizá sea la más controvertida por varios aspectos. En primer lugar por el apelitivo abarca que sucede al nombre del rey:

Figura 6.

Renovatio del E. Sepulcrale de Sancho III. (García Morilla)

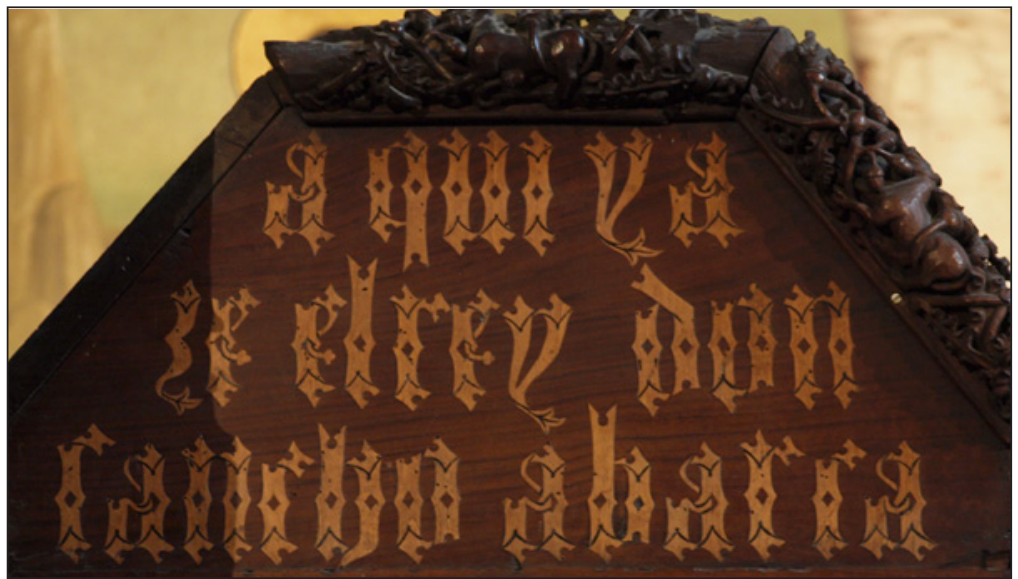

“Aqui yace elrey don Sancho Abarca”.

Para R. Del Arco no estaríamos ante la tumba de Sancho III sino ante la del abuelo de Sancho II conocido, efectivamente, como Sancho Abarca ${ }^{67}$. Sin embargo, son numerosos los estudiosos que se afanan en justificar la inclusión de tal apelativo para indicar filiación; esto es, para identificar al finado a través de sus ancestros ${ }^{68}$. Desde nuestro punto de vista esto no resulta raro pues, de alguna manera, supondría continuar con la misma dinámica que hemos visto para los sepulcros del lado de la Epístola. Además, hemos comprobado que también se mantenía este criterio en los epitafios o noticias sepulcrales extensas altomedievales. De lo que estamos seguros es que en el momento

\footnotetext{
67 Del Arco, Sepulcros de la Casa Real de Castilla, p. 83.

68 Entre las muchas justificaciones que da J. Baztán para demostrar la presencia de Sancho III en Oña señala -siguiendo a Yepes- que la del apelativo Abarca equivaldría a "Sancho el de la Casa o dinastía Abarca”. Cf. BAzTÁn, "El monasterio de San Salvador de Oña y la tumba de Don Sancho el Mayor, rey de Navarra", p. 111.
} 
de elaboración de esta Renovatio y de la actualización del panteón, Manso pretendía identificar en este sepulcro al gran rey navarro. Lo que ya no resulta tan fácil es explicar si estamos ante una equivocación o un acto intencionado.

Por su parte, las noticias del primitivo texto epigráfico son ciertamente confusas en este caso. Recogemos las palabras publicadas por Berganza al respecto:

"Ut legitur titulo, iacet hic rex Sanctius, isto, regis Garsiae pater, atque tuus Fredinande rex iste Sanctius gener comitis Sanctii fuit, pater magni regis Fredinandi, Garsiae regis navarre occisi apud Ataporcam et Ranimiri regis aragoniae, qui tandem post multas strages sarracenorum, et victorias de eis habitas, obiit Era Millesima septuagesima tertia" ${ }^{69}$.

Decimos que se trata de una información confusa porque hace mención a hechos acaecidos con posteriodad a la muerte del rey $\mathrm{Sancho}^{70}$. Bien es cierto que puede deberse a una redacción tardía del epitafio pero al no conservarse la inscripción no podemos valorar más que la información histórica que en él se recoge. Para Yepes no hay duda de que nos encontramos ante el sepulcro de este rey. En su noticia señala que a él pertence esta sepultura que está al lado de la de Sancho II. En el elogio justifica además que haya sido enterrado en este monasterio habida cuenta de los esfuerzos que realizó en vida por reformar y revitalizar esta casa:

“... Este señor rey reformó este monasterio y trajo a él monjes de San Pedro de Cluny, de Francia, y puso por primer abad de esta casa al glorioso padre San Iñigo, (...), y dió a este monasterio este señor rey grandes exenciones y libertades, porque también fué delegado del Papa en estos reinos de Castilla. Pasó de esta vida a gozar de la bienaventuranza a 18 dias del mes de octubre, año del nacimiento de Nuestro Señor Jesucristo de 1039"71.

Como decíamos, hay más elementos que alimentan la controversia sobre la ubicación original y el actual emplazamiento de los restos de Sancho III. Su custodia se la han disputado tradicionalmente el monasterio de San Salvador de Oña, la basílica de San

\footnotetext{
69 Berganza, Antigüedades de España, p. 317. En castellano reza así: "Tal como se lee en esta inscripción, aquí yace el rey Sancho, padre del rey García y tuyo también, Fernando. Este rey Sancho fue yerno del conde Sancho y padre del rey Fernando el grande, de García rey de Navarra muerto en Atapuerca y de Ramiro, rey de Aragón. Murió finalmente, tras muchas batallas contra los sarracenos y muchas victorias sobre ellos, el año 1035". Sobre la relación del sepulcro y la casa de Oña Cf. BAZTÁN, "El monasterio de San Salvador de Oña y la tumba de Don Sancho el Mayor, rey de Navarra".

70 El más llamativo es la muerte de su hijo, el rey García en la Batalla de Atapuerca a manos de su hermano Fernando en 1054, 19 años después de la desaparición de su padre.

71 De Yepes, Crónica general de la Orden de San Benito, p. 432 y García Morilla, Antonio de Yepes y la Epigrafía Medieval, p. 130.
} 
Isidoro de León y el monasterio de San Juan de la Peña de Aragón ${ }^{72}$. Es este otro factor que se suma a la escasa credibilidad que algunos autores dan tanto al epitafio original como a la presencia de los restos del gran rey en Oña ${ }^{73}$. Sin embargo, y al igual que en casos anteriores, la importancia del acto publicitario no se ve afectada y mucho menos la intencionalidad del abad Manso al "publicar" su memoria. Si la tradición recogía la presencia de los restos de Sancho el Mayor en una determinada tumba dentro de la primitiva iglesia oniense, bastaba para "resucitar" su epitafio en el panteón del siglo XV y situarlo en un lugar destacado. Por otro lado, es indiscutible la ligazón entre Oña y el monarca navarro y los beneficios que el templo burgalés había recibido en tiempo de este rey, como nos decía Yepes. Todos ellos hechos que engrandecen su historia y habían de ayudar a aumentar las peregrinaciones y fama de un cenobio en cierta decadencia. Sancho III es el monarca por excelencia del siglo XI. Su papel unificador de reinos, la europeización acaecida durante sus años de gobierno, la revitalización de las peregrinaciones, el auge del comercio y, por supuesto, el papel central de Oña en las relaciones con la monarquía vinculadas, entre otras cosas, al ejercicio del patronato, hace de este monarca la principal figura de su panteón real ${ }^{74}$.

Al lado de este sepulcro se encuentra el de doña Mayor. Hija del conde Sancho García, "el de los buenos fueros" y mujer de Sancho el Mayor de Navarra. Desde el punto de vista histórico, quizá el hecho más importante de su figura sea haber sido la llave que permitió a Sancho Garcés gobernar el condado de Castilla ${ }^{75}$. Nos encontramos ante un personaje de primera fila y capital en los avatares de la Castilla medieval que no podía faltar en el necrologio del abad Manso. Además, en este caso, no se conserva noticia del epitafio original, con lo que la renovación del siglo XV es el único testimonio epigráfico con que contamos. Incluso, como veremos a continuación, las

\footnotetext{
72 El epitafio conservado en León advierte del traslado del cuerpo a León por mandado de su hijo: "Hic situs est Sanctius Rex Perineorum montium, et Tolosae, vir per omnia catholicus, et pro ecclesia: translatus est hic a filio suo rege magno Fernando. Obiit era MCXIII”. Sobre la problemática de este epitafio y sus más que probable falsedad, cf. Rodríguez SuÁrez, "La Colegiata de San Isidoro y la imagen del poder real: el falso epigráfico de Sancho III”, pp. 441-455. La fecha recogida por Yepes para el óbito en el epitafio leonés dista mucho de la tradicionalmente reconocida de 1035. Por otro lado, en el monasterio de San Juan de la Peña también se conserva memoria del epitafio del Sancho el mayor y del traslado de sus restos: "Hic requiescit famulus Dei Sancius, rex, cuius iussu corpus Sancti Indaletii discipuli Sancti Iacobi, fuit, ex Almeria ad Ecclesiam Sancti Ioannis de Pinna translatum, quo ea qua decet reverentia habetur in altare maiori dictae ecclesiae. Obiit anno millesimo quinquagesimo octavo, in obsidione Oscae, cuius corpus ab ecclesia montis in monasterium Sancti Ioannis de Pinna, ubi nunc iacet”. Este epitafio también está extraído de la crónica de Yepes. Cf. García Morilla, Antonio de Yepes y la Epigrafía Medieval, pp. 86 y 114.

73 Por el contrario, resulta interesante la disertación de Isla Frez a favor de Oña. Cf. Isla Frez, "Oña, innovación y política en torno al año mil’, pp. 151-172.

74 Sobre el patronato en Oña cf. LADERo GARCía, "La sala capitular del monasterio de San Salvador de Oña. Patronato de los reyes de Castilla”, pp. 1 y 2.

75 Tras la muerte de su hermano, el conde García Sánchez, Sancho III se hizo con el control del condado de Castilla a través de los derechos dinásticos de su mujer doña Mayor. Cf. Martínez DíEz, Sancho III el Mayor, rey de Pamplona, Rex Ibericus, p. 84.
} 
palabras de Yepes sobre la finada son las más someras, junto con las del infante don Carlos, de todas las descripciones de los sepulcros de Oña:

"En la tercer tumba, junto a ésta -la de Sancho III-, está sepultada la muy esclarecida señora reina $D^{a}$ Mayor, hija del conde D. Sancho, señor de Castilla, y mujer del señor rey D. Sancho el Mayor, rey de Aragón y de Navarra $y$ despues de Castilla"76.

Por su parte, el texto redactado por el abad en el siglo XV reza así:

Figura 7.

Renovatio del E. Sepulcrale de doña Mayor, mujer de Sancho III. (García Morilla)

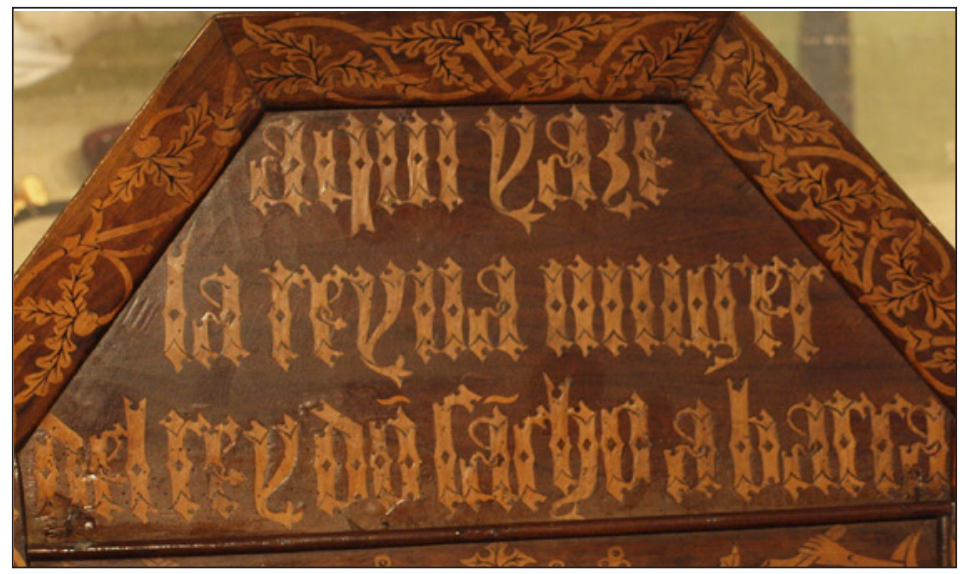

"Aqui yace la reyna muger del rey don Sancho Abarca".

En este caso en el epitafio no figura ni siquiera el nombre de la finada; muy significativo a nuestro modo de ver. Decimos significativo porque de todos los argumentos que dábamos anteriormente sobre la justificación de su sepulcro en el panteón de Oña el único que tuvo en consideración el emisor del mensaje fue el hecho de ser cónyuge del rey navarro. Declaración concluyente de la intención con la que se erigió este panteón a finales de la Edad Media. Igualmente llamativo es el hecho de que se utilice aquí de nuevo el apelativo Abarca para identificar al monarca, no habiendo duda ya de que se trata del arca de doña Mayor, y por tanto, resolviendo cualquier atisbo de duda sobre la atribución del sepulcro anterior.

76 De Yepes, Crónica general de la Orden de San Benito, p. 434 y García Morilla, Antonio de Yepes y la Epigrafía Medieval, p. 130. 
El último sepulcro del panteón es el perteneciente al infante García. Se trata del hijo de Alfonso VII y doña Berenguela. Finado en 1146, no conservamos más noticia de su epitafio que esta renovación de finales del periodo medieval ${ }^{77}$ :

\section{Figura 8.}

Renovatio del E. Sepulcrale del infante don García. (García Morilla)

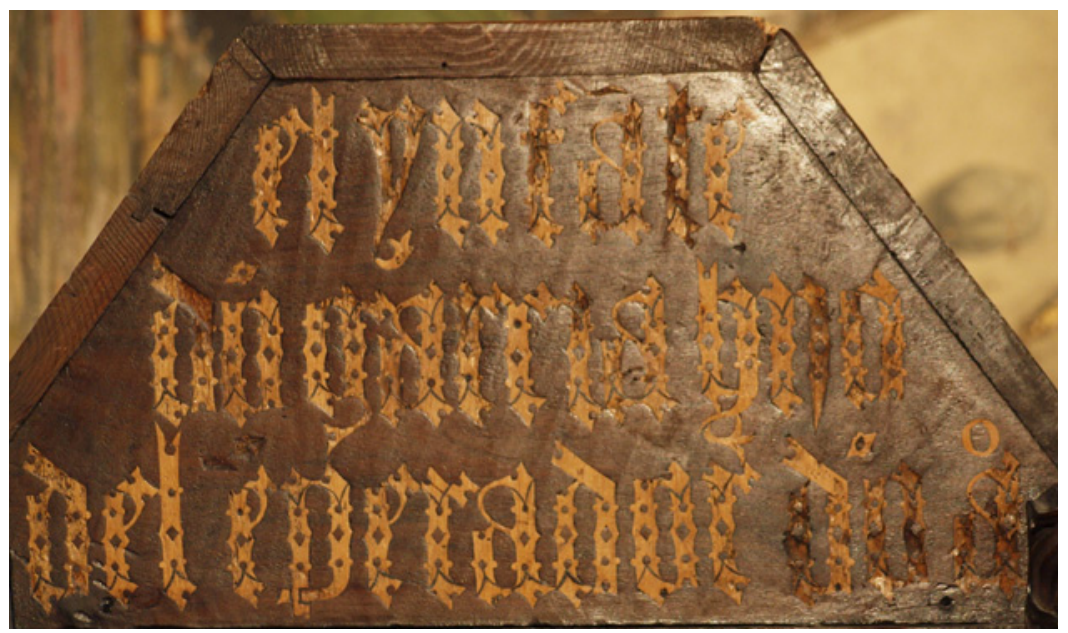

"El ynfante don Garcia hijo del enperador don Alonso".

Ya advertíamos más arriba que este era uno de los textos más escuetos de todo el panteón. Ni siquiera se sigue la fórmula habitual de los Epitaphia sepulcralia como en los casos anteriores "aquí yace". La tablilla indica únicamente la intitulación del difunto acompañada por los datos de filiación. Por contra, es interesante destacar que se abrevia el nombre del emperador y no se indica cuál de los "Alfonsos" es, lo que indica que el infante y su temprana muerte habían sido hechos que trascendieron el paso de los siglos. Esto es lógico - a diferencia de lo visto en casos anteriores similares- ya que el infante había sido educado en el monasterio y toda su vida había estado ligada a la villa de Oña ${ }^{78}$.

\footnotetext{
77 R. Del Arco recoge una noticia del padre Yepes que atribuye al infante don García: "En una tablilla sobre el sepulcro había esta inscripción, que copió el Padre Yepes: "EN LA QUARTA TUMBA ESTAN LOS HUESSOS DEL SENERENISSIMO INFANTE DON GARCIA, HIJO DEL EMPERADOR DON ALONSO DE CASTILLA". Cf. Del Arco, Sepulcros de la Casa Real de Castilla, pp. 202-203. Sin embargo, aunque bien pueda referirse a este infante, en la noticia de Yepes en realidad se recoge el epitafio del infante don Carlos: "En la cuarta tumba está los huesos del serenisimo infante don Carlos, hijo del emperador D. Alonso de Castilla", aunque el propio Yepes advierte que debe tratarse de una confusión: "este rey D. Alonso de quien aqui se trata, cuyo hijo era el infante D. García..." Cf. De YePEs, Crónica general de la Orden de San Benito, pp. 334-335 y García Morilla, Antonio de Yepes y la Epigrafía medieval, p. 131. 78 Del Arco, Sepulcros de la Casa Real de Castilla, p. 202.
} 


\section{Consideraciones epigráficas}

Estos ocho sepulcros conforman el panteón condal y real de San Salvador de Oña en la actualidad. Sin embargo, además de algunos de los primitivos textos y noticias sepulcrales de estos condes y reyes conservamos testimonio de otros enterramientos en San Salvador y, en algunas ocasiones, de sus epitafios. Yepes, además de los ya citados, recoge la noticia de los necrologios del conde don Gómez Salvadores y su mujer la condesa doña Urraca $^{79}$, del conde don Rodrigo y su mujer la condesa doña Elvira ${ }^{80}$, del camarero del conde don Sancho, don Gutiérrez Rodríguez ${ }^{81}$, del conde Gonzalo Salvadores y su hermano el conde don Nuño ${ }^{82}$ y del caballero Diego López de Villacanes ${ }^{83}$. Todo un patrimonio epigráfico que llegó a nosotros -como decíamos al comienzo de estas líneas- gracias, por un lado, a la labor de los eruditos de los siglos XVI, XVII y XVIII que nos han permitido recuperar textos hoy desaparecidos y, por otro, a esta labor renovadora del abad Manso y de su conservación hasta nuestros días. Es necesario recordar que dentro de las tareas de cualquier templo o edificio civil está la conservación y restauración de las inscripciones ${ }^{84}$. El grado de conservación, restauración y renova-

\footnotetext{
79 "Aquí están sepultados el conde don Gómez (hijo del conde D. Gonzalo Salvadores) y su mujer, la condesa doña Urraca. Este conde don Gómez y Diego de Gómez, su hermano, fueron muertos del rey Alonso de Aragón en una batalla que con él hubieron en el campo de Espina, en tiempo de la reina doña Urraca, hija del rey, D. Alonso, que ganó a Toledo. Murieron en el año del Señor de 1117, a 12 días del mes de abril". Cf. De Yepes, Crónica general de la Orden de San Benito, pp. 436 y García Morilla, Antonio de Yepes y la epigrafía Medieval, pp. 131 y 132.

80 "En esta sepultura están enterrados don Rodrigo Gómez, hijo del conde de Gómez, y su mujer la condesa Elvira, que fue en romería a visitar el santo sepulcro de Nuestro Redentor a Jerusalén y murió allá, y fue traída a sepultar con su marido a este monasterio de Oña, murió el dicho conde en tiempo del emperador D. Alonso, en el año de Señor de 1153, a 24 días del mes de septiembre". Cf. De YePes, Crónica general de la Orden de San Benito, p. 436 y García Morilla, Antonio de Yepes y la Epigrafía Medieval, p. 132.

81 "En esta sepultura está enterrado un caballero muy honrado, que fue llamado don Gutiérrez Rodríguez de Toledo, que fue camarero del muy magnifico señor conde don Sancho, que fundó este monasterio de Oña. Este don Gutiérrez pasó de esta vida a 8 días del mes de noviembre, año de la Encarnación de Nuestro Salvador, de 1027". Cf. De Yepes, Crónica general de la Orden de San Benito, p. 436 y García Morilla, Antonio de Yepes y la Epigrafía Medieval, p. 132.

82 "En esta sepultura yace el muy esforzado caballero el conde don Gonzalo de Salvadores, que fue dicho Cuatro Manos por su gran valentía, y el conde don Nuño su hermano, hijos del conde don Alvaro Salvadores, que fueron muertos a traición de los moros, con otros quince caballeros de su linaje, en un castillo de Aragón, llamado Ruela, en tiempo del rey D. Alonso, que ganó a Toledo. Fue el año del nacimiento de 1074, a 9 días de julio. Este sepulcro tiene seis escudos, en cada uno de ellos por armas un águila real" Cf. De Yepes, Crónica general de la Orden de San Benito, p. 436 y García Morilla, Antonio de Yepes y la epigrafía Medieval, p. 133.

83 "Aquí en este sepulcro está enterrado un noble caballero que se llamó don Diego López de Villacanes, que fue mayordomo del señor conde don Sancho de Castilla, el cual fundó este monasterio de Oña, y le dotó magnificamente. Y este don Diego López de Villacanes murió a 2 días del mes de agosto, en el año de la Encarnación de Nuestro Señor, de 1017”. Cf. De Yepes, Crónica general de la Orden de San Benito, p. 436 y García Morilla, Antonio de Yepes y la Epigrafía Medieval, p. 133.

84 Sobre la adecuación de las inscripciones al contexto en relación a los caracteres internos y externos Cf. De Santiago Fernández, "La Epigrafía bajomedieval”, pp. 247-276.
} 
ción de una inscripción está en estrecha relación a su funcionalidad ${ }^{85}$. Son susceptibles de ser renovadas aquellas inscripciones que si bien su mensaje sigue siendo objeto de interés para el lector, su idioma, su forma externa o su grado de conservación le impiden llegar al público contemporáneo. Es lógico, por tanto, que un texto epigráfico extenso, redactado en el latín altomedieval y en unos caracteres visigóticos y/o carolinos, fuese totalmente inaccesible para el público bajomedieval.

El proceso de desaparición de estas inscripciones arranca desde finales de la Edad Media hasta nuestros días. En buena medida tiene que ver con la pérdida de valor del edificio u objeto que las portaba y en consecuencia la pérdida de valor también del epígrafe. En otros casos, la caída o desaparición del edificio no conllevó forzosamente la destrucción del epígrafe. Fue muy frecuente que muchas inscripciones parietales desaparecieran tras procesos de restauración o enlucido de templos. Es también habitual que en actuales tareas de conservación y consolidación de restos hayan aparecido inscripciones recubiertas por yeso ${ }^{86}$. No podemos descartar que este fenómeno se de en Oña, y que en futuros procesos de restauración o en excavaciones arqueológicas aparezcan los primitivos textos. También es posible que fueran reutilizados en obras de restauración o como terrazos una vez realizadas las nuevas y ya carentes de interés publicitario ${ }^{87}$. Estas Renovationes de finales de la Edad Media y principios de la moderna fueron algo frecuente. En algunos casos hasta se deja constancia del encargo de la renovación como en el Epiaphium sepulcrale de doña Eva y su marido Jacomete de las Huelgas de Burgos, donde aún hoy podemos leer: "MANDO RENOVAR ESTOS ROTULOS EL LICENCIADO ALVARO NUÑEZ $D E$ LOAYSA" "88. El tipo de escritura, la lengua y las fórmulas adecúan el texto a los nuevos destinatarios, de manera que se garantiza de nuevo su "universalidad" y el mensaje público vuelve a entrar en circulación ${ }^{89}$. Por todo ello, nos encontramos con la paradoja de que textos breves, concisos y actualizados recobran, adecuado

\footnotetext{
85 Como ya hemos advertido más arriba, sobre la funcionalidad de las inscripciones medievales Vid. con carácter general García Lobo y Martín LóPEz, "La escritura publicitaria en la Edad Media. Su funcionalidad", pp. 142-144 y García Morilla, "De la funcionalidad de las inscripciones. El caso de monasterio de Santiago de Peñalba (León)”, pp. 273-293.

86 Tal es el caso de la inscripción de Villavés recuperada hace unos pocos años. Cf. Hernando GarRido, Martín Montes y Morda Blanco, "Un tímpano con una inscripción inédita de cronología románica en Villavés (Burgos)", pp. 33-41.

87 Este fue el caso documentado por Pérez de Urbel para un epitafio procedente de Ubierna. En la segunda visita realizada por el estudioso la inscripción fue convertida en terrazo para la ermita. Su mensaje ya no era valioso para los actuales usuarios del templo. Cf. Pérez de Urbel, El Condado de Castilla, p. 218 (nota 37).

88 Rodríguez López, El Real monasterio de las Huelgas y el Hospital del Rey, p. 252.

89 Uno de los aspectos esenciales del panteón de Oña es la adecuación de idioma y de las grafías al periodo bajo medieval -ya lo hemos dicho-. En todos los casos nos encontramos con una escritura gótica minúscula gemina muy cuidada. Esta escritura es propia del final de la Edad Media y de los albores de la Edad Moderna. Hablaríamos de los años finales del siglo XV y los primeros del siglo XVI. El prof. Calleja, que realiza un examen más exhaustivo de la misma, no ha encontrado evidencia para este caso burgalés hasta 1500 , fecha que encaja perfectamente con las particularidades epigráficas que están sucediendo en otras zonas de la provincia burgalesa como es el caso de la Cartuja de Miraflores. Cf. CAlleja Puerta, "Seis renovationes sepulcrales del monasterio de San Salvador de Oña (Burgos)", pp. 436-437.
} 
a los tiempos nuevos, el potencial publicitario que tuvieron los primitivos que, por su lengua (latina) y forma externa, resultaban inaccesibles al lector contemporáneo. Por otro lado, la propia inscripción -como medio de comunicación- cuenta con otros recursos publicitarios como es el emplazamiento de las inscripciones o la heráldica que se añade; sirven para atraer la atención del lector -con toda su intencionalidad y sus consentidos deslices $-{ }^{90}$. De todo ello es consciente el emisor del mensaje; con todo ello jugó nuestro abad Manso para realizar esta labor de marketing.

\section{Bibliografía citada}

Argáiz, Gregorio de, La Soledad Laureada por San Benito y sus hijos en las iglesias de España y teatro monástico de la provincia cartaginense, VI, ed. Bernardo de Herbada, Madrid, 1675.

AA.VV., Enciclopedia del Románico en Castilla y León, Burgos, vol. II, Fundación Santa María la Real, Aguilar de Campoo, 2003.

Bautista PéRez, Francisco, "Sancho II y Rodrigo Campeador en la Chronica Naierensis": e-Spania. Revue interdisciplinarire d'études hispaniques médiévales et modernes, 7 (2009).

BAzTÁn, Javier, "El monasterio de San Salvador de Oña y la tumba de Don Sancho el Mayor, rey de Navarra", Boletín de la Comisión de Monumentos Históricos y Artísticos de Navarra, XIV (1923), pp. 104-115.

Berganza, Francisco de, Antigüedades de España Propugnadas en las noticias de sus reyes, y condes de Castilla la Vieja: en la historia apologética de Rodrigo Diaz de Bivar dicho el Cid Campeador y en la coronica del Real monasterio de San Pedro de Cardeña, t. I, ed. Francisco del Hierro, Madrid, 1719.

Calleja Puerta, Miguel, "Seis renovationes sepulcrales del monasterio de San Salvador de Oña (Burgos)", Las inscripciones góticas: II Coloquio Internacional de Epigrafía Medieval, León del 11 al 15 de septiembre de 2006, Corpus Inscriptionum Hispaniae Mediaevalium, León, 2010, pp. 431-446.

Colomás, García-María, "Oña”, Diccionario de Historia Eclesiástica de España, ed. Consejo Superior de Investigaciones Científicas, Madrid, 1975, p. 1.612.

Corullón PARedes, Isabel, "Monacato y organización eclesiástica en la Castilla altomedieval", Burgos en la Alta Edad Media: II Jornadas burgalesas de historia, ed. Asociación Provincial de Libreros de Burgos, Burgos, 1991, pp. 587-599.

\footnotetext{
90 Bien es cierto que el estudio de la heráldica de estos sepulcros merece un capítulo completo o un artículo exclusivo. Su particular problemática histórica nos ayudaría a arrojar más luz a lo expuesto en estas líneas. Sin embargo, la limitación espacial del mismo y nuestros escasos conocimientos al respecto hacen imposible que abordemos esta cuestión con garantías. Para una primera aproximación a la cuestión cf. VAlero de Bernabé, Análisis de las características generales de la heráldica gentilicia española y de las singularidades heráldicas existentes entre los diversos territorios históricos hispanos.
} 
De Santiago Fernández, Javier, "Inscripciones en lipsanotecas y tapas de altar catalanas de los siglos X-XII. Su origen y función”, Signo. Revista de Historia de la Cultura Escrita, 10 (2002), pp. 35-62.

De Santiago Fernández, Javier, "La Epigrafía bajomedieval”, II Jornadas Científicas sobre Documentación de la Corona de Castilla (Siglos XIII-XV), Departamento de Ciencias y Técnicas Historiográficas y Arqueología (UCM), Madrid, 2003, pp. 247-276.

De Santiago Fernández, Javier, "La Epigrafía: Evolución conceptual y metodológica", Documenta et Instrumenta, 1 (2004), pp. 203-222.

De Santiago Fernández, Javier, "El programa iconográfico del monumento sepulcral de don Martín Vázquez de Arce (El Doncel de Sigüenza)”, Cuadernos de Investigación Histórica, 23 (2006).

De Santiago Fernández, Javier, "Oraciones por la salvación del alma. El obituario en piedra del monasterio de Sant Pau de Camp en Barcelona:", Anuario de Estudios Medievales, 46/2, julio-diciembre, 2016, pp. 939-973.

De Yepes, Antonio, Crónica general de la Orden de San Benito, t. II, Atlas, Madrid, 1960.

Del Arco, Ricardo, Sepulcros de la Casa Real de Castilla, Consejo Superior de Investigaciones Científicas, Madrid, 1974.

Elorza, Juan, Castillo, Belén y Negro, Marta, El Panteón Real de las Huelgas de Burgos. Los enterramientos de los reyes de León y Castilla, (2ªd.), Evergráficas, Valladolid, 1990.

FaCi LaCASta, Francisco Javier, "Sancho el Mayor de Navarra y el monasterio de San Salvador de Oña”, Peregrino. Revista del Camino de Santiago, 18 (1977), pp. 299-318. FAVreau, Robert, “L'Épigraphie médiévale”, Cahiers de civilisation médiévale, Poitiers, XIIe Année n. 4 Octobre-Décembre, 1969.

Favreau, Robert, Les inscriptions médiévales, Brepols, Turnhout, 1979.

FAVreau, Robert, Epigraphie médiévale, Brepols, Turnhout, 1997.

Flórez, Henrique, España Sagrada, Theatro geographico-historico de la iglesia de España. Origen, divisiones y límites de todas sus provincias. Antigüedad, translaciones y estado antiguo de sus Sillas, con unas Disertaciones críticas, Tomo XXVII, contiene las Iglesias colegiales, Monasterios y Santos de la Diócesis de Burgos: conventos, parroquias, y hospitales de la ciudad, con varias noticias y documentos antes no publicados, Ed. Aldecoa, Madrid, 1772 (ed. 1983).

Fuga, Antonella, Técnicas y materiales de arte, Electa, Barcelona, 2004.

García de CortázAr, José Ángel, “Organización Social del espacio burgalés en la Alta Edad Media”, Burgos en la Alta Edad Media: II Jornadas Burgalesas de Historia, ed. Asociación Provincial de Libreros de Burgos, Burgos, 1991, pp. 19-74.

García Lobo, Vicente, "Las inscripciones medievales de San Isidoro de León”, Santo Martino de León: Ponencias del I Congreso Internacional sobre Santo Martino en el VII centenario de su obra literaria 1185-1985, ed. Isidoriana, León, 1987, pp. 371-398. 
García LoBo, Vicente, "La Epigrafía Medieval. Cuestiones de Método”, Centenario de la Cátedra de "Epigrafía y Numismática" Universidad Complutense de Madrid 1900/01-2000/01, Universidad Complutense, Madrid, 2001, pp. 77-119.

GARCíA LoBo, Vicente, "El difunto reivindicado a través de las inscripciones", IX Jornadas Científicas sobre Documentación: La muerte y sus testimonios escritos, Departamento de Ciencias y Técnicas historiográficas y Arqueología, Madrid, 2011, pp. 171-198.

GARCíA LoBO, Vicente y MARTín LóPEZ, María Encarnación, "La escritura publicitaria en la Edad Media. Su funcionalidad", Estudios Humanísticos, 18 (1996), pp. 142-144. García Lobo, Vicente y Martín LóPez, María Encarnación, "La publicidad en el Císter", Monjes y monasterios: El Císter en el medievo de Castilla y León, Junta de Castilla y León, Valladolid, 1998, pp. 47-66.

García Morilla, Alejandro, "Talleres, scriptoria y pequeños centros. La producción epigráfica en la provincia de Burgos”, Documenta et Instrumenta, 12 (2014), pp. 145-193. García Morilla, Alejandro, “QQuién publica mensajes en las Catedrales?”, Lugares de escritura. La catedral: X Jornadas de la Sociedad Española de Ciencias y Técnicas Historiográficas, Universidad de Valladolid, Valladolid, 2014, pp. 313-325.

García Morilla, Alejandro, "De la funcionalidad de las inscripciones. El caso de monasterio de Santiago de Peñalba (León)”, San Miguel de Escalada (913-2013), Instituto de Estudios Medievales (ULE), León, 2014, pp. 273-293.

García Morilla, Alejandro, Antonio de Yepes y la Epigrafía Medieval, ed. Corpus Inscriptionum Hispaniae Mediaevalium, León, 2015.

Gómez BArrera, Íñigo, Oña y su Real Monasterio, Junta de Castilla y León, Madrid, 1917 [Valladolid, 2009].

Gómez Moreno, Manuel, El concepto de la Epigrafía. Consideraciones sobre la necesidad de su ampliación, Discursos leidos ante la Real Academia de la Historia por los señores D. Joaquín $M^{a}$ de Navascués y de Juan y D. Manuel Gómez-Moreno y Martínez en la recepción pública del primero, el día 18 de enero de 1953, Real Academia de la Historia, Madrid, 1953.

Hernando Garrido, José Luís, Martín Montes, Miguel Ángel y Morda Blanco, Javier, "Un tímpano con una inscripción inédita de cronología románica en Villavés (Burgos)", Boletín de la Institución de Fernán González, 210 (1995), pp. 33-41.

Isla Frez, Amancio, “Oña, innovación y política en torno al año mil”, Hispania. Revista española de Historia, 225 (2007), pp. 151-172.

Ladero García, Pilar, "La sala capitular del monasterio de San Salvador de Oña. Patronato de los reyes de Castilla", http://www.onienses.com.

Linaje Conde, Antonio, Los orígenes del monacato benedictino en la Península Ibérica, I, Consejo Superior de Investigaciones Científicas, León, 1973.

Linaje Conde, Antonio, “De los monjes a los frailes. Notas sobre la implantación de la vida religiosa en el territorio castellano-leonés", El pasado Histórico de Castilla y León, Vol. I, Edad Media, Junta de Castilla y León, Burgos, 1983, pp. 263-274. 
López SAntidrán, Saturnino, "San Íñigo, abad de Oña", Oña. Un milenio: Actas del Congreso Internacional sobre el Monasterio de Oña (1011-2011), Fundación Milenario de San Salvador de Oña, Burgos, 2012, pp. 164-177.

MARTín LóPEZ, María Encarnación, "La salvación del alma a través de las inscripciones medievales", IX Jornadas Científicas sobre Documentación: la muerte y sus testimonios escritos, Departamento de Ciencias y Técnicas Historiográficas y Arqueología, Madrid, 2011, pp. 255-279.

Martín Martínez de Simón, Elena, "Las reformas del siglo XV en la iglesia del Monasterio de San Salvador de Oña. Estado de la cuestión”, Oña. Un milenio: Actas del Congreso Internacional sobre el Monasterio de Oña (1011-2011), Fundación Milenario de San Salvador de Oña, Burgos, 2012, pp. 634-647.

Martínez DíEz, Gonzalo, El condado de Castilla (711-1038). La historia frente a la leyenda, t. II, Marcial Pons, Madrid, 2005.

Martínez Díez, Gonzalo, Sancho III el Mayor, rey de Pamplona, Rex Ibericus, Marcial Pons, Madrid, 2007.

Maté SAndornil, Lorenzo, "El monasterio de Oña en el entono de Cluny", El monasterio de San Salvador de Oña. Mil años de Historia, Fundación Milenario de San Salvador de Oña, Burgos, 2011, pp. 157-158.

Orlandis Rovira, José, "Sobre la elección de sepultura en la España medieval”: Anuario de Historia del Derecho Español, XX (1950), pp. 5-49.

Palomero Aragón, Félix, "El monasterio de San Salvador de Oña: La iglesia y entorno, su evolución y cambios desde el siglo XI al XIII", Oña. Un milenio: Actas del Congreso Internacional sobre el Monasterio de Oña (1011-2011), Fundación Milenario de San Salvador de Oña, Burgos, 2012, pp. 362-397.

Pereira García, Irene, "La Epigrafía Medieval en España: Un estado de la cuestión”: Anuario de Estudios Medievales, 47/I (2017), pp. 267-302.

Pérez de Urbel, Justo, Historia del Condado de Castilla, t. II, Consejo Superior de Investigaciones Científicas, Madrid, 1945.

Pérez de Urbel, Justo, El Condado de Castilla, Consejo Superior de Investigaciones Científicas, Madrid, 1969-1970.

Reyes Téllez, Francisco, "Los orígenes del Monasterio de San Salvador de Oña: eremitismo y monasterio", Oña. Un milenio: Actas del Congreso Internacional sobre el Monasterio de Oña (1011-2011), Fundación Milenario de San Salvador de Oña, Burgos, 2012, pp. 32-51. Rodríguez López, Amancio, El Real monasterio de las Huelgas y el Hospital del Rey, ed. Centro Católico, Burgos, 1907.

Rodríguez Muñoz, Pedro, "Iglesias Románicas Palentinas”, Publicaciones de la Institución Tello Téllez de Meneses, 13 (1955), pp. 27-126.

Rodríguez SuÁrez, Natalia, "La Colegiata de San Isidoro y la imagen del poder real: el falso epigráfico de Sancho III", Imagen del poder en la Edad Media. Estudios in memorial del prof. Fernando Galván Freile, T. II, Universidad de León, León, 2011, pp. 441-455. 
Rodríguez SuÁrez, Natalia, "Un repaso a través de los conceptos de Epigrafía e inscripción”, Documenta et Instrumenta, 10 (2012), pp. 147-154.

SÁnchez Domingo, Rafael, El régimen señorial de Castilla Vieja. La casa de los Velasco, ed. Universidad de Burgos, Burgos, 1999, p. 70.

Sánchez Domingo, Rafael, "Dominio y jurisdicción de la Abadía de Oña": Circunstancia: revista de Ciencias Sociales del Instituto Universitario de Investigación Ortega y Gasset, 24 (2011).

SÁnchez Domingo, Rafael, "Conflictos de jurisdicción con la mitra burguense. El caso de San Salvador de Oña”, Oña. Un milenio: Actas del Congreso Internacional sobre el Monasterio de Oña (1011-2011), Fundación Milenario de San Salvador de Oña, Burgos, 2012, pp. 408-441.

SenRa Gabriel y Galán, José Luis, "La irrupción borgoñona en la escultura castellana de mediados del S. XII", Anuario del Departamento de Historia y Teoría del Arte (U.A.M.), IV (1992), pp. 35-51.

Senra Gabriel y Galán, José Luís, "Arquitectura en el monasterio de San Salvador de Oña durante los siglos del románico”, Burgos en la Plena Edad Media, Asociación Provincial de Libreros de Burgos, Burgos, 1994, pp. 483-507.

Senra Gabriel y Galán, José Luís, "La implantación del románico en el Monasterio de San Salvador de Oña (siglos XI y XII”), Oña. Un milenio: Actas del Congreso Internacional sobre el Monasterio de Oña (1011-2011), Fundación Milenario del San Salvador de Oña, Burgos, 2012, pp. 568-575.

SuÁRez Bilbao, Fernando, "El monasterio de Oña en tiempos de los Trastámara”, Oña. Un milenio: Actas del Congreso Internacional sobre el Monasterio de Oña (1011-2011), Fundación Milenario de San Salvador de Oña, Burgos, 2012, pp. 136-140.

VAlero de Bernabé, Luís, Análisis de las características generales de la heráldica gentilicia española y de las singularidades heráldicas existentes entre los diversos territorios históricos hispanos, (Tesis Doctoral), ed. Universidad Complutense de Madrid, Madrid, 2007.

Viñuales Ferreiro, Gonzalo, "Economía del dominio monástico de San Salvador de Oña en la Baja Edad Media", Oña. Un milenio: Actas del Congreso Internacional sobre el Monasterio de Oña (1011-2011), Fundación Milenario de San Salvador de Oña, Burgos, 2012, pp. 396-407.

Vivancos Gómez, Miguel, "Problemática general de los monasterios benedictinos en la Plena Edad Media", Burgos en la Plena Edad Media, Asociación Provincial de Libreros de Burgos, Burgos, 1994, pp. 599-607.

Vivancos Gómez, Miguel, "En la vida y en la muerte. Estancias y sepulcros reales en San Salvador de Oña en época altomedieval": La extensión de la corte: los sitios reales, Universidad Autónoma de Madrid, Madrid, 2017, pp. 13-42.

Zabalza DuQue, Manuel, "Hallazgo del documento original de la fundación del moansterio de Oña", El pasado Histórico de Castilla y León, Junta de Castilla y León, Burgos, 1983, pp. 325-332. 
